\title{
FAKTOR YANG MEMPENGARUHI PEMBIAYAAN BAGI HASIL PADA BANK UMUM SYARIAH DI INDONESIA
}

\author{
Sasma Aprilia \\ sasmaprilia@gmail.com \\ Dewa Putra Khrisna Mahardika \\ Fakultas Ekonomi dan Bisnis, Universitas Telkom
}

diterima: 13/1/2018; direvisi: 26/2/2019; diterbitkan: 30/4/2019

\begin{abstract}
This research is conducted to measure that the capital adequacy ratio, non performing financing, and third party fund give impacts on financing of profit sharing, either simultaneously or partially. This research is a causal descriptive verification research. Unit of analysis in this research is sharia banks in Indonesia. The research data were collected by purposive sampling technique which include 7 Islamic banking that have been running for six years, in the period of 2011-2016. This study uses panel data regression. The results showed that the capital adequacy ratio, non performing financing, and third party fund simultaneously give influence to the financing of profit sharing. Partially, the capital adequacy ratio and non-performing financing does not affect the financing of profit sharing. while third party fund deposits have a positive effect on the financing of profit sharing.
\end{abstract}

Keywords: sharia bank; CAR; NPF; third party fund

\begin{abstract}
Abstrak
Penelitian ini dilakukan untuk mengukur capital adequacy ratio, non performing financing, dan simpanan dana pihak ketiga terhadap pembiayaan bagi hasil, baik secara simultan maupun parsial. Penelitian ini merupakan penelitian deskriptif verifikatif yang bersifat kausalitas. Unit analisis adalah bank umum syariah di Indonesia. Data penelitian menggunakan data sampel yang dipilih melalui teknik purposive sampling dan diperoleh 7 perbankan syariah selama enam tahun, yaitu dari tahun 2011 sampai 2016. Penelitian ini menggunakan teknik analisis regresi data panel. Hasil penelitian menunjukkan bahwa capital adequacy ratio, non performing financing, dan simpanan dana pihak ketiga berpengaruh simultan terhadap pembiayaan bagi hasil. Secara parsial, capital adequacy ratio dan non performing financing tidak berpengaruh, sedangkan simpanan dana pihak ketiga berpengaruh positif terhadap pembiayaan bagi hasil.
\end{abstract}

Kata Kunci: bank syariah; CAR; NPF; dana pihak ketiga 


\section{PENDAHULUAN}

Tidak berbeda jauh dengan bank komersial, kegiatan utama perbankan syariah adalah menghimpun dana dan menyalurkan dana ke calon peminjam (nasabah) yang membutuhkan, jumlah dana yang disalurkan bank syariah akan sangat tergantung dengan jumlah dana yang berhasil dihimpun oleh bank syariah. Bank syariah menghimpun dana menggunakan sistem bagi hasil dan sistem penitipan. Dana yang terhimpun akan berputar dalam bentuk penyalurkan melalui pembiayaan bagi hasil, pembiayaan jual beli, dan pembiyaan sewa guna mendapatkan imbal hasil yang menguntungkan bagi pihak perbankan.

Studi ini mengambil pembiayaan bagi hasil sebagai fokus dari penelitian. Pembiayaan bagi hasil pada sistem keuangan Islam merupakan bentuk produk perbankan syariah yang digunakan untuk membiayaai suatu usaha yang produktif dan halal. Pembiayaan ini diatur dan mendapat pengawasan secara langsung oleh Dewan Pengawas Syariah. Hal ini membuat sistem perbankan syariah sangat berbeda dibandingkan dengan bank komersial.

Konsep sentral dari perbankan syariah adalah keadilan dan kemaslahatan bersama yang secara umum didasarkan pada figh muamalat dimana setiap transaksi berbasis bunga, segala hal yang tidak halal, dan eksploitasi itu dilarang keras atau diharamkan dalam Islam. Dengan demikian pembiayaan bagi hasil ini memungkinkan semua pihak yang terlibat dapat berbagi resiko dan kerugian dalam rasio input modal masing-masing, sedangkan keuntungan dialokasikan pada rasio sesuai kesepakatan. Sehingga dalam hal ini tidak ada pihak yang dirugikan oleh pihak lain.

Ada dua jenis penyaluran dana dengan pembiayaan bagi hasil, yaitu kemitraan atau kerja sama satu pihak sebagai penyedia dana yang dikenal sebagai mudharabah dan kemitraan para pemodal yang dikenal sebagai musyarakah. Pada prinsipnya berdasarkan pada kontrak mudharabah yang mengatur pembiayaan bagi hasil, semua kerugian atas investasi yang dibiayai harus ditanggung oleh perbankan syariah, sementara keuntungan atas investasi ini dibagi antara bank syariah (shahibul maal) dan nasabah (mudarib) sebagai pihak yang menyediakan keahlian dalam mengelola usaha dalam proporsi yang ditentukan dalam kontrak. Namun, kerugian akibat kesalahan yang disengaja harus ditanggung oleh nasabah sesuai prinsip syariah yang berlaku. Sehingga dalam praktiknya pembiayaan ini mudah mengalami atau rentan terhadap penyimpangan karena sering kali pihak mudharib tidak melengkapi diri dengan akuntabilitas yang memadai dengan laporan keuangan yang auditable (Jamilah, 2016). Sebaliknya pada kontrak musyarakah risiko dan kerugian harus ditanggung oleh kedua belah pihak berdasarkan porsi kontribusi dana, dan keuntungan berdasarkan kesepakatan atau nisbah. Musyarakah melibatkan kemitraan yang lebih aktif antara para pemilik dana yang menyatukan modal mereka dengan yang mengelola dan mengendalikan suatu usaha bersama.

Berbeda dengan sistem konvensional, hubungan antara bank syariah dan nasabahnya didasarkan pada rasa saling percaya, diperkuat oleh kepercayaan agama atau komitmen religius, maka diharapakan bank syariah dapat memperoleh keuntungan melalui penyaluran dana dengan sistem bagi hasil yang dapat meningkatkan produktifitas dan kinerja perbankan syariah mengingat populasi muslim di Indonesia yang sangat besar.

Namun pada kenyataannya sistem bagi hasil mengalami beberapa kendala sehingga membuat pihak perbankan enggan menempatkan sebagian besar portofolio asetnya pada sistem pembiyaan berbasis bagi hasil. Sistem bagi hasil dianggap terlalu beresiko, dimana bank syariah sulit memprediksi berapa laba yang diperoleh dari pembiayaan proyek, karena besarnya laba yang diperoleh tergantung dari keberhasilan proyek yang dibiayai dan bank syariah dituntut untuk menganalisis dan mengawasi proyek secara ketat atau bahkan dapat dituntut untuk terlibat secara aktif sejak tahap persiapan sampai tahap operasi proyek guna meningkatkan keberhasilan proyek yang dibiayai (Mahardika, 2015).

Berdasarkan Tabel 1 menunjukkan pembiayaan bank syariah didominasi oleh pembiayaan jual beli yaitu kontrak (akad) Murabahah sebesar Rp.139.536 triliun pada tahun 2016 atau 56\%, ini berarti lebih dari setengah pembiayaan yang diberikan bank syariah pada sektor rill masih didominasi oleh skema piutang. Sedangkan porsi pembiayaan pada skema bagi hasil hanya mencapai Rp. 15.292 triliun pada tahun 2016 atau setara dengan $6 \%$ saja.

Berdasarkan Tabel 2 bahkan secara nasional market share perbankan syariah masih sangat kecil, padahal jika sistem bunga bank dilarang atau diharamkan, bisa diharapkan bahwa market share asset perbankan syariah di setiap negara muslim terutama di Indonesia setidaknya setara dengan dengan jumlah penduduk muslim yang ada, karena semua muslim harus dan wajib memilih bank Islam dari pada bank konvensional yang sudah sangat jelas diharamkan.

Potensi pasar perbankan syariah yang sangat besar di Indonesia belum dimanfaatkan secara optimal. Dengan market share yang baru mencapai 5\% bank syariah masih sangat jauh dengan bank komersial. Hal ini dikarenakan pemahaman masyarakat yang masih rendah serta adanya tawaran produk-produk konvensional yang lebih murah mengakibatkan kecenderungan masyarakat masih memilih lembaga keuangan konvensional dan di satu sisi kebijakan pemerintah yang masih belum berpihak terhadap keuangan syariah. (Linangkung,2016)

Kecilnya pembiayaan bagi hasil dibandingkan dengan pembiayaan jual beli atau skema piutang di Indonesia menjadi salah satu kendala market share perbankan syariah masih rendah. Sehingga hal ini perlu 
dikaji lebih lanjut. Beberapa faktor yang kemungkinan mempengaruhi pembiayaan bagi hasil pada bank syariah di Indonesia yaitu, Capital Adequacy Ratio (CAR), Non Performing Financing (NPF), Dan Simpanan Dana Pihak Ketiga (DPK). Faktor-faktor tersebut telah diteliti oleh beberapa peneliti terdahulu.

Capital Adequacy Ratio (CAR) merupakan faktor utama bank syariah dalam mengembangkan pertumbuhan usahanya. Berdasarkan peraturan Bank Indonesia tentang kewajiban penyediaan modal minimum (KPMM) Pasal 2 Nomor 14/18/PBI/2012 Ayat 3 bank wajib menyediakan modal minimum sebesar $8 \%$ dari asset tertimbang menurut risiko (ATMR). Semakin tinggi nilai Capital Adequacy Ratio mengindikasikan bahwa bank syariah semakin mampu untuk menanggung risiko dari adanya berbagai pembiayaan yang mungkin berisiko terutama untuk pembiayaan bagi hasil. Jika semakin tinggi nilai Capital Adequacy Ratio yang dimiliki bank syariah, maka bank akan mampu membiayaai berbagai kegiatan operasional serta memberikan kontribusi secara maksimal pada hal-hal yang berkaitan dengan profitabilitas perbankan syariah yang diperoleh melalui penyaluran dana dengan pembiayaan bagi hasil. Sehingga apabila rasio kecukupan modal meningkat maka akan meningkatkan penyaluran dana bank syariah pada pembiayaan bagi hasil. Penelitian Jamilah (2016) dan Asri (2016) menyatakan bahwa Capital Adequacy Ratio berpengaruh signifikan dengan arah positif terhadap pembiayaan bagi hasil. Sedangkan penelitian yang dilakukan oleh Husaeni (2017) menyatakan bahwa Capital Adequacy Ratio tidak berpengaruh signifikan terhadap pembiayaan bagi hasil.

Non Performing Financing (NPF) merupakan kredit bermasalah yang terdiri dari kredit yang diklasifikasikan macet atau kurang lancar dan berdampak negatif terhadap pengembalian aset. NPF mencerminkan risiko kredit yang ditanggung oleh pihak bank (Ali, 2008) Semakin tinggi NPF maka semakin tinggi tingkat pembiayaan kurang lancar atau bermasalah yang membuat biaya operasional meningkat secara keseluruhan dan menurunkan tingkat imbal hasil secara keseluruhan yang membuat penyaluran dana pada bank syariah semakin rendah. Dalam penelitian yang dilakukan oleh Purnomo (2015) membuktikan bahwa Non Performing Financing berpengaruh signifikan terhadap pembiayaan pada bank syariah. Dan penelitian Jamilah (2016), Kalkarina (2016), Husaeni (2017) menyatakan bahwa Non Performing Financing tidak berpengaruh signifikan terhadap pembiayaan pada bank syariah di Indonesia.

Simpanan Dana Pihak Ketiga menurut undangundang perbankan No.10 tahun 1998 merupakan dana yang dipercayakan oleh masyarakat kepada bank berdasarkan perjanjian penyimpanan dana. Semakin tinggi tingkat dana yang dihimpun oleh bank syariah maka semakin tinggi tingkat dana yang akan disalurkan oleh bank syariah melalui pembiayaan bagi hasil.
Menurut penelitian yang dilakukan oleh Kalkarina (2016) menunjukkan bahwa simpanan dana pihak ketiga memiliki pengaruh signifikan terhadap pembiayaan bagi hasil pada bank syariah di Indonesia. Begitupun dengan penelitian yang dilakukan oleh Jamilah (2016) dan Husaeni (2017) yang menyatakan bahwa simpanan dana pihak ketiga berpengaruh signifikan terhadap pembiayaan pada bank syariah di Indonesia.

Hubungan antara capital adequacy ratio, non performing financing, dan simpanan dana pihak ketiga terhadap pembiayaan bagi hasil digambarkan dalam bentuk kerangka pemikiran yang tersaji dalam Gambar 1.

\section{METODE}

Operasionalisasi variabel ditunjukkan pada Tabel 3. Populasi dalam penelitian ini adalah 13 Bank Umum Syariah yang terdaftar di OJK periode 20112016. Data yang digunakan adalah data sekunder, yaitu laporan keuangan perbankan syariah. Sampel dipilih menggunakan teknik purposive sampling dengan kriteria: Bank Umum Syariah yang terdaftar di OJK periode 2011-2016, Bank Umum Syariah yang memiliki peringkat kinerja terbaik periode 2016 dengan pemeringkatan syariah 2017- Litbang Majalah Investor, Bank Umum Syariah yang memiliki modal inti Rp 1 Triliun sampai dengan di bawah Rp 30 Triliun periode 2016, Bank Umum Syariah yang menyajikan laporan keuangan secara konsisten selama periode 2011-2016. Dari kriteria tersebut, didapat 7 perbankan syariah dengan periode penelitian selama enam tahun untuk diteliti (Tabel 4). Teknik analisis data yang digunakan adalah analisis regresi data panel.

\section{HASIL}

Hasil analisis statistik deskriptif dari variabel independen dan dependen ditunjukkan pada Tabel 5. Capital Adequacy Ratio (CAR) dan Non Performing Financing (NPF) memiliki nilai rata-rata yang lebih tinggi dari standar deviasinya. Artinya sampel yang digunakan dapat mewakili seluruh populasinya. Sedangkan Pembiayaan Bagi Hasil dan Dana Pihak Ketiga memiliki nilai rata-rata lebih rendah dibandingkan standar deviasinya, yang berarti sampel yang digunakan belum dapat mewakili seluruh populasinya.

Berdasarkan hasil uji Chow pada Tabel 6, diperoleh nilai (cross section chi square) dan (cross section F) masing-masing 0.0000 dan 0.0000 lebih kecil dari taraf signifikansi $\alpha=5 \%$, sehingga penelitian ini lebih tepat menggunakan fixed effect dibandingkan common effect. Selanjutnya dilakukan pengujian untuk pemilihan model antara fixed effect dengan random effect menggunakan uji Hausman.

Berdasarkan hasil uji Hausman pada Tabel 7, diperoleh nilai (cross-section random) sebesar 0,9453 
lebih besar dari taraf signifikansi $\alpha=5 \%$, sehingga model yang tepat digunakan dalam penelitian ini adalah Random Effect.

Tabel 8 menunjukkan bahwa model memiliki nilai R-Square sebesar $65,02 \%$ hal ini mengindikasikan bahwa variabel dependen yang dapat dijelaskan oleh variabel independen adalah sebesar $65,02 \%$, sedangkan sisanya 34,98\% dijelaskan oleh variabel independen lain diluar penelitian ini. Dengan Prob (F-statistic) 0.000000, sehingga secara simultan Capital Adequacy Ratio, Non Performing Financing, dan Simpanan Dana Pihak Ketiga berpengaruh signifikan terhadap Pembiayaan Bagi Hasil.

\section{PEMBAHASAN}

Nilai rata-rata $\mathrm{PBH}$ pada perbankan syariah di Indonesia selama tahun 2011-2016 sebesar Rp 5.798.392 triliun lebih kecil dari standar deviasinya yang bernilai Rp 6.694.072 triliun, sehingga data cenderung bervariasi atau tidak berkelompok.

Pembiayaan bagi hasil yang disalurkan bank umum syariah pada kurun waktu 2011-2016 rata-rata terus mengalami peningkatan. Salah satu Bank Umum Syariah dengan penyaluran pembiayaan terbesar dari tahun ke tahun adalah perbankan Muamalat Indonesia. Dimana pembiayaan bagi hasil yang disalurkan sebesar Rp 21,729,544 triliun. Kemudian disusul oleh perbankan mandiri syariah dengan penyaluran pembiayaan terbesar kedua yaitu sebesar Rp16,489,863 triliun pada tahun 2016. DPK yang besar menjadi salah satu indikasi meningkatnya penyaluran pembiayaan bagi hasil pada bank muamalat Indonesia dan mandiri syariah. Selain itu usia yang terbilang mapan atau sudah cukup lama berdiri sebagai perusahaan perbankan syariah, menjadi salah satu dari sekian banyaknya faktor yang mempengaruhi besarnya pembiayaan bagi hasil yang disalurkan.

Capital Adequacy Ratio merupakan hasil perbandingan dari seluruh aset yang menjadi hak milik bank syariah dan modal bersih yang dimiliki. Berdasarkan Tabel 5 menunjukkan bahwa rata-rata CAR pada perbankan syariah di Indonesia selama tahun 2011-2016 sebesar 19.62\% lebih besar dari standar deviasinya yang bernilai $10.28 \%$, sehingga data cenderung berkelompok atau tidak bervariasi.

Kemampuan bank dalam permodalan dengan jumlah tertinggi pada kurun waktu 2011-2016 dimiliki oleh Bank Panin Dubai Syariah sebesar 61,98\%. Diikuti oleh Bank BCA Syariah dengan nilai 36,78\% yang berarti nilai tersebut barada diatas rata-rata CAR perbankan syariah. Sedangkan nilai CAR terendah dimiliki oleh bank Muamalat Indonesia selama 3 tahun, 2011 sebesar 11,97\% kemudian pada tahun 2015 dan 2016 sebesar $12,00 \%$ dan $12,74 \%$. Walapun dengan CAR terendah Bank Muamalat Indonesia memiliki pertumbuhan CAR dari tahun ke tahun yang cenderung meningkat, begitupun dengan perbankan syariah lainnya. Dalam laporan perkembangan keuangan syariah, hal ini disebabkan karena BUS melakukan penambahan setoran dari pemegang saham utama (induk). Dan pada tahun 2016 Total setoran modal BUS dimaksud sebesar \pm Rp2 triliun (termasuk sukuk subordinasi). Kapasitas permodalan bank dalam mengantisipasi risiko (risk bearing capacity) juga tercermin dari jumlah modal inti yang meningkat sebesar Rp 3.49 triliun atau 18,48\%, serta total modal yang meningkat Rp3.56 triliun $(15,22 \%)$, Sementara aset terimbang menurut risiko (ATMR) BUS meningkat sebesar 8,51\%.

Non Performing Finance (NPF) merupakan rasio pembiayaan yang bermasalah di suatu bank. NPF diukur dengan membandingkan total pembiayaan bermasalah dengan total pembiayaan yang disalurkan perbankan syariah. Tingkat pembiayaan bermasalah (NPF) pada BUS mengalami fluktuasi yang cukup signifikan. Pada tahun 2011-2016 NPF terendah dialami oleh Bank BCA Syariah. Sedangkan untuk NPF tertinggi dialami oleh Bank BRI Syariah dari tahun 2012,2013, dan 2016 yang masing-masing sebesar $1,84 \%, 3,26 \%$, dan 3,19\%. Sedangkan pada tahun 2014-2015 NPF tertinggi dimiliki oleh Bank Muamalat Indonesia sebesar 4,76\% dan $4,20 \%$. mengindikasikan bahwa rasio NPF yang tinggi berarti kualitas pembiayaan lebih baik. Keuangan tinggi diikuti oleh kenaikan rasio NPF. Dimana perbankan syariah secara keseluruhan dari tahun ke tahun tidak melampaui batas maksimum sebesar 5\%, umumnya mengindikasikan bahwa bank syariah masih dianggap sehat.

Jumlah NPF yang cenderung meningkat pada beberapa BUS kemungkinan disebabkan karena di luar control nasabah, size perbankan syariah yang masih kecil seperti ketersediaan infrastruktur dan network (jaringan) perbankan syariah belum menjangkau sampai ke pelosok, sehingga jika ada satu nasabah yang jatuh akan mempengaruhi secara keseluruhan. Rata-rata NPF yang dialami oleh 7 BUS masih berada dibawah 5\% yakni 1,83\% lebih besar dari standar deviasinya yang bernilai $1,30 \%$, sehingga data cenderung berkelompok atau tidak bervariasi.

Simpanan Dana Pihak Ketiga merupakan dana yang dipercayakan oleh masyarakat kepada bank. jumlah DPK pada BUS secara keseluruhan terus meningkat. Pada kurun waktu 2011-2016 DPK yang berhasil dihimpun dengan jumlah tertinggi secara berturut-turut dimiliki oleh Bank Mandiri Syariah yang pada tahun 2016 mencapai $\mathrm{Rp}$ 69.949.861 triliun tumbuh sebesar $21 \%$ atau Rp 7.836 .982 triliun. Sedangkan DPK dengan nilai terendah dimiliki oleh Bank Panin Dubai Syariah pada tahun 2011 sebesar Rp 419.772 dan Bank BCA Syariah berturut-turut dari tahun 2012-2016.

Peningkatan DPK yang terus mengalami peningkatan dari tahun ke tahun menunjukkan tingkat kepercayaan masyarakat yang menitipkan dananya di bank syariah semakin membaik. Hal tersebut didukung oleh peningkatan layanan industri jasa keuangan syariah 
yang senantiasa berupaya mengoptimalkan infrastruktur dan memberikan service excellence kepada masyarakat, di antaranya pemanfaatan IT dan peningkatan jumlah kantor cabang serta pemanfaatan layanan syariah (LS) dan layanan syariah bank (LSB).

Tahun 2011-2016, DPK perbankan syariah masih didominasi oleh deposito sebesar 59,37\%, diikuti oleh tabungan sebesar 31,02\% dan giro sebesar 9,60\%. Dan pada Tabel 5 menunjukkan bahwa rata-rata DPK pada perbankan syariah di Indonesia selama tahun 2011-2016 sebesar Rp 20.066.870 triliun lebih kecil dari standar deviasinya yang bernilai Rp 20.347.823 triliun sehingga data cenderung bervariasi atau tidak berkelompok.

Pada Tabel 8, CAR memiliki Koefisien sebesar -3139038 dengan probabilitas 0,3877 diatas $\alpha=5 \%$, sehingga Capital Adequacy Ratio tidak berpengaruh terhadap Pembiayaan Bagi Hasil. Artinya besar atau kecilnya CAR yang dimiliki perbankan syariah tidak mencerminkan jumlah besar atau kecilnya pembiayaan bagi hasil yang akan disalurkan BUS. Tidak adanya pengaruh yang signifikan antara CAR dengan PBH dapat dilihat dari rata-rata rasio kecukupan modal (CAR) yang kuat sebesar 20\% secara keseluruhan pada perbankan syariah tahun 2011-2016, dimana angka tersebut jauh dari tingkat minimum $8 \%$ yang telah ditetapkan. Sehingga dapat diartikan perbankan syariah memiliki tingkat kecukupan modal yang tinggi, dengan hal tersebut memiliki peluang yang besar untuk memperbesar penyaluran pembiayaan bagi hasilnya kepada masyarakat guna memberikan kontribusi secara maksimal pada profitabilitas perbankan syariah. Hal ini tidak sesuai dengan hipotesis yang dilakukan oleh peneliti, bahwa CAR berpengaruh signifikan dengan arah positif terhadap pembiayaan bagi hasil. Menurunnya CAR tidak selalu mempengaruhi volume pembiayaan bagi hasil karena profit dari pembiayaan itu sendiri dapat meningkatkan penyaluran pembiayaan bagi hasil. Hasil penelitian ini tidak sesuai dengan penelitian yang dilakukan oleh Jamilah (2016) yang menyatakan bahwa Capital Adequacy Ratio berpengaruh positif terhadap Pembiayaan Bagi Hasil pada Perbankan Syariah.

Pada Tabel 8, NPF memiliki Koefisien sebesar 2797118 dengan probabilitas 0,9283 diatas $\alpha=5 \%$, sehingga NPF tidak berpengaruh terhadap Pembiayaan Bagi Hasil. Artinya menerima H02 dan menolak Ha2 yang menyatakan bahwa NPF berpengaruh signifikan dengan arah negatif terhadap pembiayaan bagi hasil. Arah positif menunjukkan NPF berbanding lurus terhadap besar kecilnya pembiayaan bagi hasil yang dilakukan oleh bank syariah. Hal tersebut mengindikasikan bahwa masih ada faktor penentu lain yang lebih diutamakan sebagai pertimbangan kebijakan penyaluran pembiayaan bagi hasil pada perbankan syariah. Hasil penelitian ini tidak sesuai dengan penelitian yang dilakukan oleh Asri (2016) yang menyatakan bahwa Non Performing Financing berpengaruh terhadap Pembiayaan Bagi Hasil pada Perbankan Syariah.
DPK memiliki Koefisien sebesar 0.314564 dengan probabilitas 0.0000 diatas $\alpha=5 \%$, sehingga Dana Pihak Ketiga berpengaruh terhadap Pembiayaan Bagi Hasil atau hipotesis $\mathrm{Ha} 3$ diterima. Hal ini menunjukkan bahwa semakin besar DPK yang dihimpun bank syariah, maka semakin besar jumlah dana yang dapat dimanfaatkan bank syariah untuk melaksanakan penyaluran pembiayaan bagi hasil. Dimana jumlah dana yang disalurkan di sisi lending tergantung pada dana yang berhasil dihimpun di sisi funding. Artinya jika bank syariah tidak berhasil menghimpun dana (DPK), maka kegiatan penyaluran dana tidak akan berjalan. Dengan demikian, jika BUS mampu berinovasi dan menarik minat masyarakat Indonesia yang mayoritas penduduknya adalah muslim untuk menginvestasikan dananya dengan jalan yang halal, maka perbankan syariah yang ada akan semakin pesat dan dapat meningkatkan market share bank syariah secara nasional. Hasil penelitian ini sesuai dengan penelitian yang dilakukan oleh Kalkarina (2016) yang menyatakan bahwa Dana Pihak ketiga memiliki pengaruh signifikan terhadap Pembiayaan Bagi Hasil pada Perbankan Syariah.

\section{KESIMPULAN}

Rata-rata pembiayaan bagi hasil perbankan syariah pada tahun 2011-2016 adalah berkisar Rp 5.798.392 triliun. Capital adequacy ratio rata-rata sebesar 19,62\%. Non performing financing rata-rata sebesar 1,83\%. Dana pihak ketiga rata-rata sebesar Rp 20.066.870 triliun.

Capital adequacy ratio, non performing financing, dan simpanan dana pihak ketiga berpengaruh simultan terhadap pembiayaan bagi hasil. Secara parsial, capital adequacy ratio dan non performing financing tidak berpengaruh terhadap pembiayaan bagi hasil. sedangkan simpanan dana pihak ketiga berpengaruh positif terhadap pembiayaan bagi hasil.

\section{DAFTAR PUSTAKA}

Ali, Masyhud. 2008. Manajemen Resiko. Jakarta: PT Raja Grafindo Persada.

Asri, Aida Sania. 2016. Analisis Faktor-Faktor Yang Mempengaruhi Pembiayaan Berbasis Bagi Hasil Pada Perbankan Syariah. Jurnal Manajemen, Vol.5(3), Hal.1-15. Universitas Diponegoro Semarang (ISSN 2337-3792)

Bank Indonesia. 1998. UU No. 10 Tahun 1998 tentang Perbankan. Didapat dari: http://www.bi.go.id/id/ tentang-bi/uu-bi/Documents/uu_bi_1099.pdf

Bank Indonesia. 2012. Peraturan Bank Indonesia No.14/18/PBI/2012 Kewajiban Penyediaan Modal Minimum Bank Umum.

Husaeni, Uus Ahmad. 2017. Determinan Pembiayaan Pada Bank Pembiayaan Rakyat Syariah di Indonesia. Jurnal Bisnis dan Manajemen, Vol.7(1), Hal.1-14. Universitas Suryakancana. (P-ISSN 2087-2038) 
Jamilah. 2016. Faktor-Faktor Yang Mempengaruhi Pembiayaan Mudharabah Pada Bank Umum Syariah Di Indonesia. Jurnal Ilmu dan Riset Akuntansi, Vol.5(4), Hal.1-20. Sekolah Tinggi Ilmu Ekonomi Indonesia Surabaya. (ISSN : 2460-0585)

Kalkarina, Samira. 2016. Faktor-Faktor yang Mempengaruhi Pembiayaan Berbasis Bagi Hasil Pada Bank Umum Syariah di Indonesia. Jurnal Bisnis dan Ekonomi, Vol.3, Hal.1-7. Universitas Telkom Bandung. (ISSN 2355-9357)

Kasmir. 2012. Bank dan Lembaga Keuangan Lainnya. Jakarta: PT Raja Gafindo Persada.

Linangkung, Erfanto. 2016, 18 Mei. Ini Penyebab Pasar Syariah Masih Kecil. Sindo News. [online]. Tersedia:

Tabel 1. Komposisi Pembiayaan BUS dan UUS

\begin{tabular}{lrrrrrr}
\hline \multicolumn{1}{c}{ Akad } & 2011 & 2012 & 2013 & 2014 & 2015 & 2016 \\
\hline Mudharabah & $10 \%$ & $8 \%$ & $7 \%$ & $7 \%$ & $7 \%$ & $6 \%$ \\
Musyarakah & $18 \%$ & $19 \%$ & $22 \%$ & $25 \%$ & $29 \%$ & $32 \%$ \\
Murabahah & $55 \%$ & $60 \%$ & $60 \%$ & $59 \%$ & $57 \%$ & $56 \%$ \\
Salam & $0 \%$ & $0 \%$ & $0 \%$ & $0 \%$ & $0 \%$ & $0 \%$ \\
Istishna & $0 \%$ & $0 \%$ & $0 \%$ & $0 \%$ & $0 \%$ & $0 \%$ \\
Ijarah & $4 \%$ & $5 \%$ & $6 \%$ & $6 \%$ & $5 \%$ & $4 \%$ \\
Qardh & $13 \%$ & $8 \%$ & $5 \%$ & $3 \%$ & $2 \%$ & $2 \%$ \\
\hline
\end{tabular}

Sumber : Otoritas Jasa Keuangan, 2017

Tabel 2. Indikator Perkembangan Perbankan Syariah (dalam miliyaran rupiah)

\begin{tabular}{|c|c|c|c|c|c|c|}
\hline & 2012 & 2013 & 2014 & 2015 & 2016 & $\begin{array}{c}\text { Juli } \\
2017\end{array}$ \\
\hline $\begin{array}{l}\text { A s e t } \\
\text { B a n k } \\
\text { Syariah }\end{array}$ & 195.018 & 242.276 & 272.343 & 296.262 & 356.504 & 378.569 \\
\hline$\%$ & $4 \%$ & $5 \%$ & $5 \%$ & $5 \%$ & $5 \%$ & $5 \%$ \\
\hline $\begin{array}{l}\text { Pembi- } \\
\text { a y a a n } \\
\text { B a n k } \\
\text { Syariah }\end{array}$ & 147.505 & 184.122 & 199.330 & 213.000 & 248.009 & 264.338 \\
\hline$\%$ & $5 \%$ & $5 \%$ & $5 \%$ & $5 \%$ & $5 \%$ & $6 \%$ \\
\hline $\begin{array}{l}\text { D P K } \\
\text { B a n k } \\
\text { Syariah }\end{array}$ & 147.512 & 183.534 & 217.858 & 231.175 & 279.335 & 307.638 \\
\hline$\%$ & $4 \%$ & $5 \%$ & $5 \%$ & $5 \%$ & $5 \%$ & $6 \%$ \\
\hline
\end{tabular}

Data diatas tidak termasuk dana dari Bank Pengkreditan Rakyat Syariah

Sumber: Statistik Perbankan Syariah Juni 2017 (OJK, 2017) https://ekbis.sindonews.com/read/1109197/178/ ini-penyebab-pasar-syariah-indonesia-masihkecil-1463474113

Mahardika, Dewa P.K. 2015. Mengenal Lembaga Keuangan. Bekasi: Gramata Publishing.

Meydianawathi, Luh Gede. 2007. Analisis Perilaku Penawaran Kredit Perbankan Kepada Sektor UMKM di Indonesia (2002-2006). Buletin Studi Ekonomi Vol. 12 No. 12. Didapat dari: http://eprints. uny.ac.id/5022/

Otoritas Jasa Keuangan. Perbankan Syariah [online]. Tersedia: http://www.ojk.go.id

Umam, Khaerul. 2013. Manajemen Perbankan Syariah. Bandung: CV. Pustaka Setia.

\begin{tabular}{cl}
\multicolumn{2}{c}{ Tabel } \\
\hline No. Sampel Bank Umum Syariah \\
\hline 1. & \multicolumn{1}{c}{ Bamk Bank Bank Syariah } \\
2. & Bank Syariah Mandiri \\
3. & Bank BRI Syariah \\
4. & Bank Muamalat Indonesia \\
5. & Bank Panin Dubai Syariah \\
6. & Bank BCA Syariah \\
7. & Bank Mega Syariah \\
\hline
\end{tabular}

Tabel 5. Hasil Pengujian Statistik Deskriptif

\begin{tabular}{rrrrr}
\hline & \multicolumn{1}{c}{ Mean } & \multicolumn{1}{c}{ Maximum } & Minimum & \multicolumn{1}{c}{ Std. Dev. } \\
\hline PBH & $5,798,392$ & $21,955,269$ & 33,275 & $6,694,072$ \\
CAR & 0.196248 & 0.619751 & 0.113508 & 0.102827 \\
NPF & 0.01834 & 0.0476 & 0.001 & 0.013016 \\
DPK & $20,066,870$ & $69,949,861$ & 419,772 & $20,347,823$ \\
\hline
\end{tabular}

Sumber: Data sekunder yang telah diolah

Tabel 6. Uji Likelihood Test Ratio

Redundant Fixed Effects Tests

Equation: FE

Test cross-section fixed effects

\begin{tabular}{llrl}
\hline \multicolumn{1}{c}{ Effects Test } & Statistic & \multicolumn{1}{c}{ d.f. } & Prob. \\
\hline Cross-section F & 26.734371 & $(6,32)$ & 0.0000 \\
Cross-section Chi-square & 75.342666 & 6 & 0.0000 \\
\hline
\end{tabular}


Tabel 7. Uji Hausman

Correlated Random Effects - Hausman Test

Equation: RE

Test cross-section random effects

\begin{tabular}{cccc}
\hline Test Summary & Chi-Sq. Statistic & Chi-Sq. d.f. & Prob. \\
\hline Cross-section random & 0.375305 & 3 & 0.9453 \\
\hline
\end{tabular}

Sumber: Output Eviews 10 (data diolah)

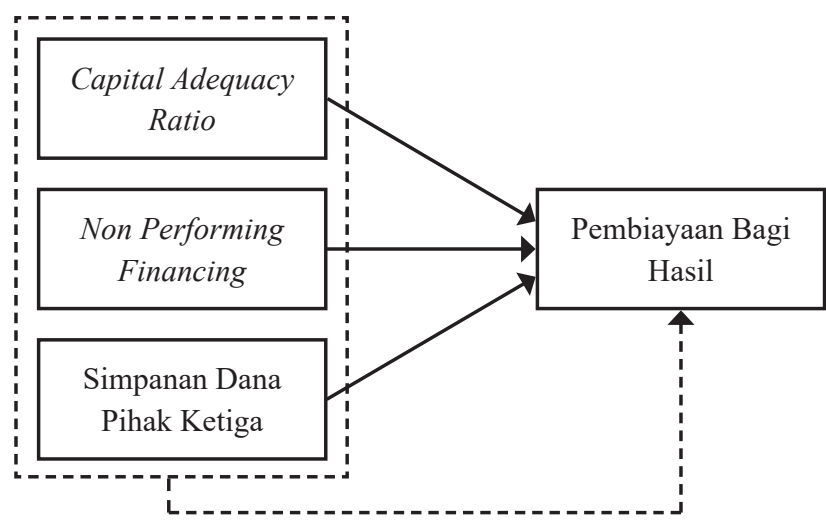

Keterangan:

$----\rightarrow$ : Berpengaruh secara Simultan

$\longrightarrow$ : Berpengaruh secara Parsial

Gambar 1. Kerangka Pemikiran
Tabel 8. Hasil Pengujian Random Effect Model

Method: Pooled EGLS (Cross-section random effects)

Sample: 16

Included observations: 6

Cross-sections included: 7

Total pool (balanced) observations: 42

Swamy and Arora estimator of component variances

\begin{tabular}{lrrrr}
\hline \multicolumn{1}{c}{ Variable } & Coefficient & Std. Error & t-Statistic & Prob. \\
\hline C & 50803.83 & 2074398. & 0.024491 & 0.9806 \\
CAR? & -3139038. & 3592168. & -0.873856 & 0.3877 \\
NPF? & 2797118. & 30888315 & 0.090556 & 0.9283 \\
DPK? & 0.314564 & 0.046833 & 6.716759 & 0.0000 \\
\hline \multicolumn{5}{c}{ Weighted Statistics } \\
\hline R-squared & 0.650216 & Mean dependent var & 801614.6 \\
Adjusted & 0.622602 & S.D. dependent var & 2442744. \\
R-squared & 1500645. & Sum squared resid & $8.56 \mathrm{E}+13$ \\
S.E. of & \multicolumn{5}{c}{ Durbin-Watson stat } & 0.736077 \\
regression & 23.54618 & & \\
$\begin{array}{l}\text { F-statistic } \\
\text { Prob(F- } \\
\text { statistic) }\end{array}$ & 0.000000 & & \\
\hline Sumber: Output Eviews 10 (data diolah) &
\end{tabular}

Tabel 3. Operasionalisasi Variabel

\begin{tabular}{ccc}
\hline Variabel dan Konsep & Indikator & Skala \\
\hline
\end{tabular}

Pembiayaan Bagi Hasil (Y) adalah kontrak pembiayaan suatu proyek. Dalam kontrak ini, bank menyediakan dana dan nasabah menyediakan dana dan keahlian. Sebelum menjalankan proyek bersama, bank syariah dan nasabah menetapkan porsi bagi hasil jika proyek memperoleh laba/rugi. (Mahardika,2015)

Capital Adequacy Ratio $\left(\mathrm{X}_{1}\right)$ merupakan kemampuan bank dalam permodalan yang ada untuk menutup kemungkinan kerugian di dalam pembiayaan (Umam, 2013)

$$
\mathrm{CAR}=\frac{\text { Modal }}{\mathrm{ATMR}} \times 100 \%
$$

Rasio

Non Performing Financing $\left(\mathrm{X}_{2}\right)$ adalah Persentase jumlah pembiayaan bermasalah yang diklasifikasikan macet atau kurang lancar. (Meydianawathi, 2007)

$\mathrm{NPF}=\frac{\text { Total Pembiayaan Bermasalah }}{\text { Total Pembiayaan }} \times 100 \% \quad$ Rasio

Simpana Dana Pihak Ketiga $\left(\mathrm{X}_{3}\right)$ adalah dana yang berasal dari masyarakat baik perorangan maupun badan, sumber dana ini merupakan sumber dana terpenting bagi kegiatan operasi bank dan merupakan ukuran keberhasilan bank jika mampu membiayaai operasinya dari sumber daya dana pihak ketiga (Kasmir, 2011)
Dana Pihak Ketiga $=$ Giro + Tabungan + Deposito

Rasio Sumber : Data yang telah diolah 